(c) Inra/Elsevier, Paris

Note

\title{
Demographic characterization, inbreeding and maintenance of genetic diversity in the endangered Catalonian donkey breed
}

\author{
Pilar Folch, Jordi Jordana* \\ Unitat de Genètica i Millora Animal, Departament de Patologia i Producció Animals, \\ Facultat de Veterinària, Universitat Autònoma de Barcelona, \\ 08193-Bellaterra, Barcelona, Spain
}

(Received 20 November 1997; accepted 1 March 1998)

\begin{abstract}
This study characterizes the demographic and genealogical structure of a limited-size population in danger of extinction: the Catalonian donkey breed. The purpose of this paper is to establish the most suitable breeding criteria and guidelines to achieve the 'Programme of Conservation and Maintenance of Animal Genetic Resources' in this population. The two main objectives proposed are: 1) to maintain the maximum genetic diversity, with 2) the minimum possible consanguinity increase per generation. A population size of 109 animals of both sexes, 44 males and 65 females, was analysed. The pedigree information was used to calculate the following items: generation length $(L)$, variances of family size $\left(\sigma_{k}^{2}\right)$, effective population size $\left(N_{\mathrm{e}}\right)$, inbreeding coefficient $(F)$ and probability of gene origin. The results obtained and breeding criteria to be followed are discussed. The correct mating policy between a stallion and a jenny would be that which would maximize the so-called genetic conservation index and minimize the inbreeding coefficient of the hypothetical offspring of the couple. (C) Inra/Elsevier, Paris
\end{abstract}

donkey / endangered breed / pedigree analysis / demographic structure / genetic diversity maintenance

Résumé - Caractérisation démographique, consanguinité et entretien de la variabilité génétique de la race asine Catalane. Le présent travail caractérise la structure démographique et généalogique d'une population en voie d'extinction : la race asine Catalane. La finalité de ce travail a été d'établir les critères et normes de reproduction les plus appropriés pour développer le «programme de conservation et entretien des ressources génétiques animales» pour cette population. Les deux principaux objectifs proposés sont : 1) l'entretien d'une quantité maximale de diversité génétique, avec 2) le minimum d'augmentation possible de consanguinité par génération. La taille de la population analysée a été de 109 animaux des deux sexes, 44 mâles et 65 femelles. L'information qui

\footnotetext{
* Correspondence and reprints

E-mail: jordana@guara.uab.es
} 
provient des généalogies a été utilisée pour calculer les paramètres suivants : intervalles entres générations $(L)$, variance pour la taille de la famille $\left(\sigma_{k}^{2}\right)$, taille effective de la population $\left(N_{\mathrm{e}}\right)$, coefficient de consanguinité $(F)$ et probabilité de l'origine des gènes. Les résultats obtenus, ainsi que les normes reproductives seront analysés, considérant qu'un accouplement optimal entre un étalon et une ânesse sera celui qui maximise le dénommé Indice de Conservation Génétique et celui qui minimise la consanguinité d'un descendant hypothétique du couple en question. (C) Inra/Elsevier, Paris

âne / race en voie d'extinction / analyse de généalogies / structure démographique / entretien de la variabilité génétique

\section{INTRODUCTION}

The Catalonian donkey is a local tame donkey breed located in several Pyrenean and pre-Pyrenean regions of the Catalonian area of northeast Spain. This population is in danger of extinction. The last census carried out only slightly surpassed 100 animals, a third of which were males [10].

Following the guidelines proposed by the FAO, investigations were first carried out on morphological traits [4], on haematological and clinical biochemical parameters $[7,11]$ and on genetic loci $[5,6]$, to characterize this breed.

A small and homogeneous population, has important problems derived from inbreeding. Therefore, the two priorities accounted for in the Catalonian donkey breed Conservation Programme are: 1) keeping the maximum genetic diversity, 2) obtaining the lowest possible inbreeding rate per generation. The purpose of this paper is to characterize demography and to analyse the pedigree structure of this population in danger of extinction, to set up the breeding criteria to fit to these objectives.

\section{MATERIALS AND METHODS}

The data file information corresponds to the period 1979-1996. The breed population analysed consisted of 109 individuals, distributed between 39 foals of both sexes ( $<3$ years old; 18 males and 21 females) and 70 adults: 26 males (aged 3-14) and 44 females (aged 3-18). The pedigree information was used to compute: generation length $(L)$, variances of family size $\left(\sigma_{k}^{2}\right)$, effective population size $\left(N_{\mathrm{e}}\right)$, inbreeding coefficient and probability of gene origin.

The $N_{\mathrm{e}}$ computation was obtained from the formula proposed by [9]

$$
\begin{aligned}
\frac{1}{N_{\mathrm{e}}}=\frac{1}{16 N_{\mathrm{m}} L}[2+ & \left.\sigma_{\mathrm{mm}}^{2}+2\left(\frac{N_{\mathrm{m}}}{N_{\mathrm{f}}}\right) \operatorname{cov}_{(\mathrm{mm}, \mathrm{mf})}+\left(\frac{N_{\mathrm{m}}}{N_{\mathrm{f}}}\right)^{2} \sigma_{\mathrm{mf}}^{2}\right] \\
& +\frac{1}{16 N_{\mathrm{f}} L}\left[2+\left(\frac{N_{\mathrm{f}}}{N_{\mathrm{m}}}\right)^{2} \sigma_{\mathrm{fm}}^{2}+2\left(\frac{N_{\mathrm{f}}}{N_{\mathrm{m}}}\right) \operatorname{cov}_{(\mathrm{fm}, \mathrm{ff})}+\sigma_{\mathrm{ff}}^{2}\right]
\end{aligned}
$$

where $N_{\mathrm{m}}$ and $N_{\mathrm{f}}$ are, respectively, adults males and females with offspring and $L$ as the average of the generation intervals calculated for the four pathways. Let $\operatorname{cov}_{(\mathrm{mm}, \mathrm{mf})}$ be the covariance of the number of male and female progeny from each 
male parent and $\operatorname{cov}_{(\mathrm{fm}, \mathrm{ff})}$ from each female parent. The variances in family size are expressed as: $\sigma_{\mathrm{mm}}^{2} ; \sigma_{\mathrm{mf}}^{2} ; \sigma_{\mathrm{fm}}^{2} ; \sigma_{\mathrm{ff}}^{2}$.

The inbreeding coefficient $(F)$ was calculated for every animal in the file, using a computer programme based on Quaas-Henderson's algorithm $[8,16]$. The evolution of the average coefficient of inbreeding was observed over year of birth and summarized by the linear regression over years.

The probability of gene origin was calculated from the genetic contributions of the founders of the current population $[2,3,13,15]$. A founder is defined as an ancestor with unknown parents in the file.

This effective number of founders $\left(f_{\mathrm{e}}\right)$ is equivalent to the so-called Genetic Conservation Index (GCI) proposed by Alderson [1], which shows the relative capacity of an individual to retain the ancestral genetic variability

$$
f_{\mathrm{e}}=1 / \sum_{k=1}^{f} q_{k}^{2}
$$

where each founder $k$ can be characterized by the expected contribution $q_{k}$ to the gene pool considered; $f_{\mathrm{e}}$ can be calculated for an individual or a group of individuals (by definition, the sum of $q_{k}$ s is equal to one). If the founder contributions are balanced, the effective number of founders is equal to $f$. Otherwise, $f$ is lower $[2,3]$.

\section{RESULTS AND DISCUSSION}

\subsection{Demographic parameters}

When using the formula proposed by Hill [9], an $N_{\mathrm{e}}$ value of 59.97 was obtained. If our objective is to try to maximize this $N_{\mathrm{e}}$, i.e. to minimize the inbreeding increase per generation $(\Delta F)$, then we can see according to equation (1), that a series of factors exists that would allow us to increase this $N_{\mathrm{e}}$.

\subsubsection{Generation interval}

The average generation interval between parents and offspring was $6.74 \pm 1.66$ years, the maternal interval $(7.32 \pm 2.95)$ being larger than the paternal one $(6.16 \pm 1.55)$, even though the differences between both were not statistically significant. The maternal interval was more variable than the paternal one because their variation coefficients (CV) were, respectively, $40.3 \%$ and $25.1 \%$. The generation interval according to the four gene transmission pathways were the following: $L_{\mathrm{ss}}=6.15 \pm 1.90 ; L_{\mathrm{sd}}=6.17 \pm 2.45 ; L_{\mathrm{dd}}=7.42 \pm 4.75 ; L_{\mathrm{ds}}=7.21 \pm 3.51$, with $\mathrm{s}=$ sires and $\mathrm{d}=$ dams.

The average age of the parents at birth of their first offspring was $4.23 \pm 1.57$ years among stallions and $5.37 \pm 3.89$ years among jennies. The average reproductive life was $2.85 \pm 3.42$ and $2.77 \pm 3.37$ years, respectively. Despite this, there was no significant differences between sex, which would indicate that the annual replacement rates are similar among the male and female subpopulations. 
The generation lengths are determined by age at first mating and by reproductive life. These parameters and the total offspring that parents leave to the next generation are directly affected by the breeding policy. On the other hand, the effective population size would increase if these generation intervals would rise [9].

Generation intervals which have been described in horse breeds by other authors, since there are not any references in the donkey species, show a $L$ value much greater than ours. For example, both Moureaux et al. [15], analysing French race and riding horses and Klemetsdal [12], analysing Norwegian trotters, obtained an average $L$ of 10-12 years. According to Moureaux et al. in their study, the reason for their intervals being higher than ours, is due to the fact that the animals analysed were to be exploited for sport. This means that the sporting career preceded the breeding life, whereas the donkeys analysed here are only used for breeding. It could possibly be the reason why no significant differences have been found between the generation lengths of males and females in our breed.

\subsubsection{Family size variances}

Progeny size was $4.0 \pm 4.82$ per stallion and $2.28 \pm 1.34$ per jenny. The family size distribution for males is more unbalanced than in females because there are a few stallions with more than ten offspring, approximately three times as many as the average number of offspring per male. In contrast, few jennies had more than four foals, and then, females show a greater breeding homogeneity than males. The family size variances calculated along the four pathways for gametes confirm the previous remarks: $\sigma_{\mathrm{mm}}^{2}=7.66 ; \sigma_{\mathrm{mf}}^{2}=5.83 ; \sigma_{\mathrm{fm}}^{2}=0.90 ; \sigma_{\mathrm{ff}}^{2}=0.90$ offspring.

\subsubsection{Male/female proportion (sex ratio)}

When analysing this population census and its breeding structure, two types of problems can be observed. The adult female percentage $(62.85 \%)$ nearly doubles the male proportion (37.14\%), 44 females versus 26 males. On the other hand, the number of adult males and females which are breeding is less than half the number of adult individuals which could potentially be used as reproducers $\left(N_{\mathrm{f}}=21\right.$ and $N_{\mathrm{m}}=12$ ).

In short, we would recommend increasing the $N_{\mathrm{e}}$ population, to try to equalize the sex ratio $\left(n_{\mathrm{m}} \approx N_{\mathrm{f}}\right)$ and to use the maximum number of adult animals which are now present in our population.

To conclude, and directing these results to the Conservation Programme, the main objective would be to maximize the effective population size $\left(N_{\mathrm{e}}\right)$ to guarantee that increments of consanguinity per generation would be minimal: 1) equalize the sex ratio $\left(N_{\mathrm{m}} \approx N_{\mathrm{f}}\right)$ avoiding the family size fluctuations and that ideally, each male would contribute with a male offspring and each female with a female offspring to the next generation, 2) standardize the family size minimizing the variance $\left(\sigma_{k}^{2}\right)$, and 3) increase the generation intervals, that is, lengthen the reproductive life of the animals. 


\subsection{Inbreeding and pedigree completeness}

The annual average inbreeding $(\Delta F)$, calculated by linear regression over years, was $0.38 \%$ (figure 1 ). The accumulated consanguinity average $(F)$ was $5.9 \%$. The expected theoretical inbreeding increase was calculated from $\Delta F=1 / 2 N_{\mathrm{e}}$ which gave a result of $0.83 \%$ in the studied population.

The pedigree completeness degree [14] was measured for each animal in the study by calculating the proportion of ancestors known in each preceding generation (figure 2). The pedigree thoroughness was found to be very incomplete up to the fifth generation of ancestors because the proportion of known ancestors was less than $20 \%$. That is why this situation should be taken into account when analysing the inbreeding coefficients.

\subsection{Probability of gene origin}

The effective number of founders $\left(f_{\mathrm{e}}\right)$, according to the formula (2), was 51.31 ancestors, the total number of founders $\left(f_{\mathrm{t}}\right)$ was 85 . However, we considered that the total number of founders was very high basically due to the poor quality of pedigree information. According to Boichard et al. [3], these individuals do not represent the genetic variability which exists in the current population. In the first place, because these animals have possibly been considered as founders and, as a result, genetically independent, their relationship is virtually zero, but perhaps this is not true. In the second place, because the contributions of the present population are very unbalanced owing to the fact that some founders have contributed very little or even not at all.

Analysing the relationship $f_{\mathrm{e}} / f_{\mathrm{t}}$ a result of $60.36 \%$ was obtained, that is, for every ancestor contributing effectively to the genetic pool in the population under

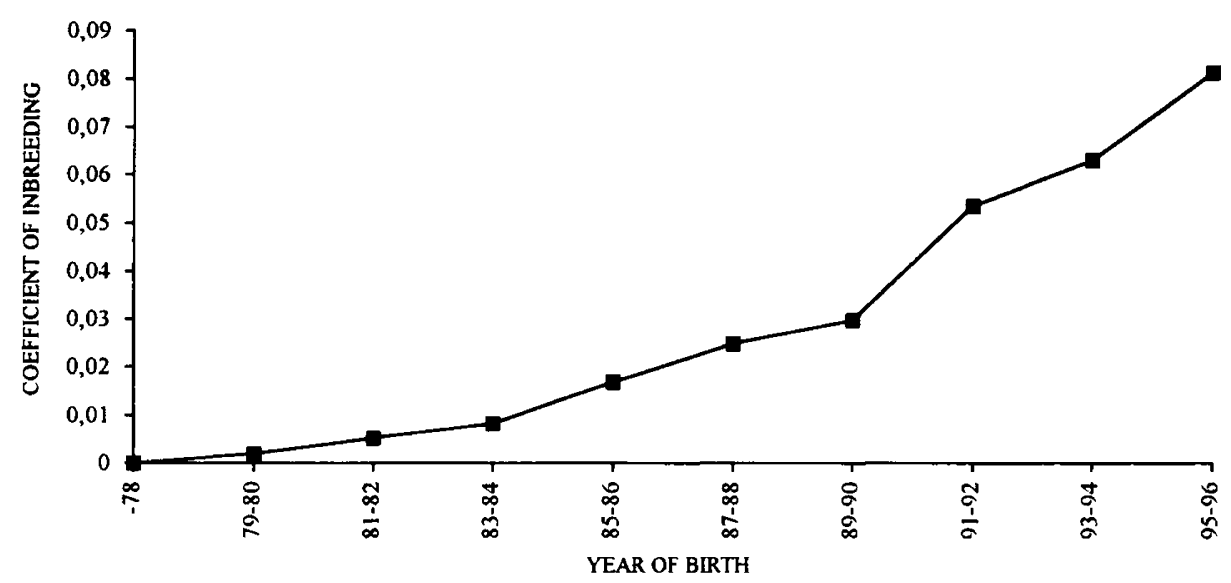

Figure 1. Average biannual coefficient of inbreeding in offspring born between 1979 and 1996. 


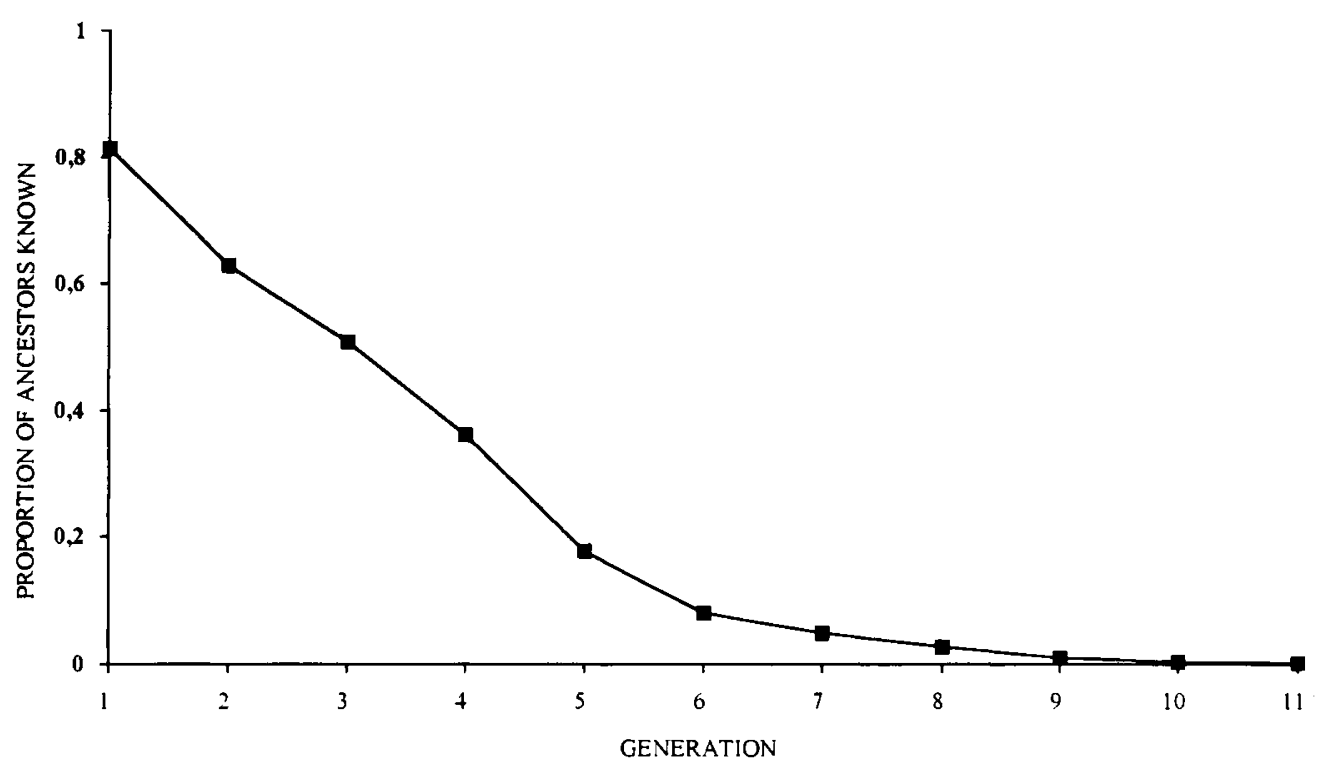

Figure 2. Average proportion of ancestors known by generation for the Catalonian donkey (1979-1996).

study there is another for whom information has been lost. This relationship has been described in French horse populations [15]. It was noticed that they have ranged from $2.78 \%$ to $14.03 \%$, where some populations, such as the Trotteur Français, were particularly very unbalanced (only $1 \%$ of founders accounted for half the current gene pool). Probably these imbalances are due to the fact that the selection intensity in these populations is very high and that they use only the best stallions for matings.

To maintain and to conserve a small population, a correct mating system is very important. On the whole, an ideal breeding policy would be that which would calculate the effective number of founders and the inbreeding coefficient of the hypothetical offspring of each possible populating couple. In this way, those couples which would maximize this effective founder number and minimize the offspring inbreeding coefficient would be chosen.

\section{CONCLUSION}

We must ensure the equal contribution of the maximum number of animals possible (from both sexes), with as much time as possible, leaving offspring for the next generation. A minimum number of inbreeding matings should be allowed. A maximum number of founder animals (ideally all of them) would then be represented in the next generation. 


\section{ACKNOWLEDGEMENTS}

The authors wish to thank the Departament d'Agricultura, Ramaderia i Pesca of the Generalitat de Catalunya, which financed this study; likewise the AFRAC association for their helpful contribution and for providing the data used in the analysis. Also, the authors are grateful to E. Bedmar for providing a computer program for inbreeding and probability gene-origin calculations as well as his computation assistance throughout this paper. Also, we would like to thank Chuck Simmons for the English revision.

\section{REFERENCES}

[1] Alderson G.L.H., A system to maximize the maintenance of genetic variability in small populations, in: Alderson L., Bodó I. (Eds.), Genetic Conservation of Domestic Livestock, CAB International, Wallingford, 1992, pp. 18-29.

[2] Boichard D., Maignel L., Verrier E., Analyse généalogique des races bovines laitières françaises, Inra Prod. Anim. 9 (1996) 323-335.

[3] Boichard D., Maignel L., Verrier E., The value of using probabilities of gene origin to measure genetic variability in a population, Genet. Sel. Evol. 29 (1997) 5-23.

[4] Folch P., Jordana J., Characterization, reference ranges and the influence of gender on morphological parameters of the endangered Catalonian donkey breed, J. Equine Vet. Sci. 17 (1997) 102-111.

[5] Folch P., Jordana J., Estado actual de resultados del Programa de Conservación Genética en la raza asnal Catalana, ITEA Suppl. 18 (1997) 348-350.

[6] Folch P., Jordana J., Sánchez A., Genetic variation of the endangered Catalonian donkey breed, Anim. Genet. 27 (S2) (1996) 34.

[7] Folch P., Jordana J., Cuenca C., Reference ranges and the influence of age and sex on haematological values of the endangered Catalonian donkey breed, Vet. J. 154 (1997) $163-168$.

[8] Henderson C., A simple method for computing the inverse of a numerator relationship matrix used in the prediction of breeding values, Biometrics 32 (1976) 69-83.

[9] Hill W.G., Effective size of populations with overlapping generations, Theor. Popul. Biol. 3 (1972) 278-289.

[10] Jordana J., Folch P., The endangered Catalonian donkey breed: the main ancestor of the American ass or Mammoth, J. Equine Vet. Sci. 16 (1996) 436-441.

[11] Jordana J., Folch P., Cuenca C., Clinical biochemical parameters of the endangered Catalonian donkey breed: normal values and the influence of sex, age and management practices effect, Res. Vet. Sci. (1998) (in press).

[12] Klemetsdal G., Demographic parameters and inbreeding in the Norwegian Trotter, Acta Agric. Scand. A-An. 43 (1993) 1-8.

[13] Lacy R.C., Analysis of founder representation in pedigrees: founder equivalents and founder genome equivalents, Zoo Biol. 8 (1989) 111-123.

[14] MacCluer J.W., Boyce A.J., Dyke B., Weitkamp L.R., Pfenning D.W., Parsons C.J., Inbreeding and pedigree structure in Standardbred horses, J. Hered. 74, (1983) 394-399.

[15] Moureaux S., Verrier É., Ricard A., Mériaux J.C., Genetic variability within French race and riding horse breeds from genealogical data and blood marker polymorphism, Genet. Sel. Evol. 28, (1996) 83-102.

[16] Quaas R.L., Computing the diagonal elements and inverse of a large numerator relationship matrix, Biometrics 32 (1976) 949-953. 